\title{
Optimization of lactic acid production from whey by $L$ casei NRRL B-441 immobilized in chitosan stabilized Ca-alginate beads
}

\author{
Y Göksungur, ${ }^{1 *} M$ Gündüz ${ }^{2}$ and Ş Harsa ${ }^{2}$ \\ ${ }^{1}$ Ege University, Faculty of Engineering, Food Engineering Department, 35100 Bornova, İmir, Turkey \\ ${ }^{2}$ Izmir Institute of Technology, Faculty of Engineering, Food Engineering Department, Gulbahce, 35437 Urla Izmir, Turkey
}

\begin{abstract}
The production of lactic acid from whey by Lactobacillus casei NRRL B-441 immobilized in chitosan-stabilized Ca-alginate beads was investigated. Higher lactic acid production and lower cell leakage were observed with alginate-chitosan beads compared with Ca-alginate beads. The highest lactic acid concentration $\left(131.2 \mathrm{~g} \mathrm{dm}^{-3}\right)$ was obtained with cells entrapped in $1.3-1.7 \mathrm{~mm}$ alginate-chitosan beads prepared from $2 \%(\mathrm{w} / \mathrm{v}) \mathrm{Na}$-alginate. The gel beads produced lactic acid for five consecutive batch fermentations without marked activity loss and deformation. Response surface methodology was used to investigate the effects of three fermentation parameters (initial sugar, yeast extract and calcium carbonate concentrations) on the concentration of lactic acid. Results of the statistical analysis showed that the fit of the model was good in all cases. Initial sugar, yeast extract and calcium carbonate concentrations had a strong linear effect on lactic acid production. The maximum lactic acid concentration of $136.3 \mathrm{~g} \mathrm{dm}^{-3}$ was obtained at the optimum concentrations of process variables (initial sugar $147.35 \mathrm{~g} \mathrm{dm}^{-3}$, yeast extract $28.81 \mathrm{~g} \mathrm{dm}^{-3}, \mathrm{CaCO}_{3} 97.55 \mathrm{~g} \mathrm{dm}^{-3}$ ). These values were obtained by fitting of the experimental data to the model equation. The response surface methodology was found to be useful in optimizing and determining the interactions among process variables in lactic acid production using alginate-chitosan-immobilized cells.
\end{abstract}

(C) 2005 Society of Chemical Industry

Keywords: lactic acid; whey; calcium alginate; chitosan; immobilized L casei; response surface methodology

\section{INTRODUCTION}

Lactic acid is a product with a wide variety of industrial applications, among the most important being its use as a preservative and acidulant in foods ${ }^{1}$ and as a precursor for polymers such as poly(lactic acid). ${ }^{2}$ It is commercially produced by fermentation of corn sugars, molasses and whey with homofermentative lactic acid bacteria. ${ }^{3}$ Whey is a major by-product of the dairy industry which serves as an inexpensive medium for lactic acid production. It contains approximately $(\mathrm{w} / \mathrm{v}) 5 \%$ lactose, $1 \%$ protein, $0.4 \%$ fat and some minerals. It has a high BOD content, which presents serious disposal problems. ${ }^{4}$

Immobilization of whole cells has been widely used for lactic acid production since immobilization exhibits many advantages such as relative ease of product separation, reuse of biocatalysts, high volumetric productivity, improved process control and reduced susceptibility of cells to contamination. ${ }^{5}$ The entrapment of cells in calcium alginate gel beads is the most widely used method for viable lactic acid bacteria immobilization owing to its simplicity, non-toxicity, mild gelation conditions and ease of use. ${ }^{5,6}$ However, alginate gels are susceptible to cation chelating agents such as phosphate and lactate, which can cause instability of the beads. In lactic acid production, calcium ions that stabilize this type of gel are displaced by lactate ions produced by lactic acid bacteria, leading to disruption or dissolution of the beads. ${ }^{78}$ Another drawback of using Ca-alginate in cell immobilization is cell leakage from the beads. Cells on and near the surface can easily leak from the beads into the medium and subsequently grow much more rapidly in the medium than in the beads. ${ }^{9}$

Many attempts have been made to improve the stability of Ca-alginate beads, such as covering the beads with poly-L-lysine ${ }^{10}$ or treating the beads with polyethyleneimine, ${ }^{6,11,12}$ glutaraldehyde ${ }^{11,12}$ and hexamethylenediamine. ${ }^{11}$ Coating Ca-alginate beads with chitosan is another method to increase the stability of the beads. Chitosan ( $\beta$-1,4-D-glucosamine) is the deacetylated form of chitin $(\beta-1,4-N$-acetyl-Dglucosamine), which is the second most abundant natural biopolymer after cellulose. ${ }^{13}$ When alginate (strongly acidic polyanion) is mixed with chitosan (strongly basic polycation), strong ionic interactions

* Correspondence to: Y Göksungur, Ege University, Faculty of Engineering, Food Engineering Department, 35100 Bornova, izmir, Turkey E-mail: yekta@food.ege.edu.tr

(Received 6 November 2004; revised version received 1 March 2005; accepted 15 March 2005)

Published online 26 May 2005 
between the carboxyl residues of the alginate and the amino termini of the chitosan occur to form a polyelectrolyte complex, which is insoluble in common solvents and highly permeable to watersoluble microsolutes. This complex does not dissolve in the presence of $\mathrm{Ca}^{2+}$ chelators or anti-gelling cations and hence can be used to stabilize the gel and reduce the porosity of the alginate beads. ${ }^{14}$

The stabilization of Ca-alginate beads by coating with chitosan has been investigated by a number of researchers for Saccharomyces cerevisiae cells, ${ }^{8}$ a model enzyme $(\beta \text {-galactosidase })^{15}$ and Yarrowia lipolytica yeast. ${ }^{12}$ Gåserød et $a l^{16}$ studied the binding of chitosan to alginate beads quantitatively by using radioactively labeled fractions of chitosan. Gåserød et $a l^{17}$ examined the stability and permeability of the alginate-chitosan complex as a function of the content and distribution of chitosan in the gel beads. To our knowledge, only two papers on lactic acid production by bacteria immobilized in chitosan-coated alginate beads have been published. Yoo et al ${ }^{18}$ produced lactic acid with a productivity of more than $2.7 \mathrm{~g} \mathrm{dm}^{-3} \mathrm{~h}^{-1}$ using $L$ case $i$ cells immobilized in chitosan-coated Ba-alginate beads. Zhou et $a l^{19}$ investigated the effect of chitosan coating of alginate beads on Lactobacillus lactis ssp cremoris release from the beads. They found that the main effect of chitosan coating was to decrease the rate of cell release during early stages of fermentation.

Response surface methodology (RSM) is a collection of statistical techniques for designing experiments, building models, evaluating the effect of factors and searching for optimum conditions for desirable responses. RSM can identify and quantify the various interactions among different parameters and it has been extensively applied for optimization of cultural medium conditions and other process parameters in bioprocesses. ${ }^{20}$ The optimization of lactic acid production from beet molasses by free cells of Lactobacillus delbrueckii using RSM has been described. ${ }^{21,22}$ The production of lactic acid from whey permeate by immobilized lactic acid bacteria cells has been reported. ${ }^{23-29}$

The present study examined lactic acid production from whey by $L$ casei NRRL B-441 immobilized in alginate-chitosan beads. The effects of initial sugar concentration, Na-alginate concentration and bead size on lactic acid production were studied. RSM was used to optimize fermentation parameters to obtain maximum lactic acid concentration. The optimized fermentation parameters were initial sugar, yeast extract and $\mathrm{CaCO}_{3}$ concentrations. These parameters are among the most important factors for lactic acid production. This study seems to be the first detailed work on both optimization and production of lactic acid from whey using $L$ casei immobilized in alginate-chitosan beads.

\section{MATERIALS AND METHODS Microorganism}

Lactobacillus casei NRRL B-441 used throughout this study was kindly supplied by the US Department of Agriculture, National Center for Agricultural Utilization Research. The strain is maintained in litmus milk and transferred to fresh medium every month. Active cultures for immobilization were grown in MRS broth at $37^{\circ} \mathrm{C}$ for $24 \mathrm{~h}$.

\section{Culture media}

Whey powder containing 60-62\% (w/w) lactose was obtained from PINAR Dairy Products, Izmir, Turkey. Unless stated otherwise, whey powder was dissolved to contain a $145.5 \mathrm{~g} \mathrm{dm}^{-3}$ initial lactose concentration and supplemented with yeast extract $10, \mathrm{~K}_{2} \mathrm{HPO}_{4}$ 0.5, $\mathrm{KH}_{2} \mathrm{PO}_{4} 0.5, \mathrm{MgSO}_{4} 0.2$ and $\mathrm{MnSO}_{4} \cdot \mathrm{H}_{2} \mathrm{O} 0.05 \mathrm{~g} \mathrm{dm}^{-3}$. Whey medium ( $\mathrm{pH}$ 5.5) and salt solutions were sterilized separately at $121^{\circ} \mathrm{C}$ for $15 \mathrm{~min}$. Sterile $\mathrm{CaCO}_{3}(50 \%$ (w/w) of the initial lactose concentration) was added to the medium to neutralize the acid formed and to maintain the mechanical structure of the gel beads. ${ }^{5}$ In the optimization studies using RSM, the concentrations of initial sugar (lactose), yeast extract and $\mathrm{CaCO}_{3}$ were varied as parameters, while the levels of other medium components were kept constant. All chemicals were purchased from Merck (Darmstadt, Germany), except yeast extract, which was purchased from Oxoid (Hampshire, UK).

\section{Cell immobilization}

$L$ casei cells grown in $25 \mathrm{~cm}^{-3}$ MRS broth were mixed with an equal volume $(1: 1, \mathrm{v} / \mathrm{v})$ of $4 \% \mathrm{Na}-$ alginate (Sigma, A-2033) solution. A $50 \mathrm{~cm}^{-3}$ aliquot of alginate cell suspension containing $2 \% \mathrm{Na}$-alginate was added dropwise with a peristaltic pump to a hardening solution of $400 \mathrm{~cm}^{-3}$ containing $2 \%$ (w/v) $\mathrm{CaCl}_{2}, 0.5 \%(\mathrm{w} / \mathrm{v})$ chitosan (Aldrich, medium $\mathrm{MW})$ and $1 \%(\mathrm{v} / \mathrm{v})$ acetic acid. Alginate drops solidified upon contact with $\mathrm{CaCl}_{2}$, forming beads and thus entrapping bacterial cells. The beads were allowed to harden for $30 \mathrm{~min}$. The beads were then washed with sterile physiological solution $(0.85 \%$ $\mathrm{NaCl}$ ) to remove excess calcium ions and cells. Immediately after entrapment, the number of living cells was $2.32 \times 10^{8} \mathrm{cfug}^{-1}$ beads. To increase the entrapped cell population the beads were incubated overnight in the whey medium at $37^{\circ} \mathrm{C}$ and the number of entrapped bacterial cells increased to $2.56 \times 10^{9} \mathrm{cfu} \mathrm{g}^{-1}$ beads. The beads were stored at $4{ }^{\circ} \mathrm{C}$ until used.

The fermentation kinetics of Ca-alginate-chitosan beads were also compared with those of Ca-alginate beads. These beads were prepared by the above method except that chitosan and acetic acid were not used in the hardening solution.

\section{Fermentation conditions}

Fermentations were carried out batchwise in $250 \mathrm{~cm}^{3}$ flasks with a $100 \mathrm{~cm}^{3}$ working volume in a temperature-controlled flask shaker operated at $150 \mathrm{rpm}$ and $37^{\circ} \mathrm{C}$. The flasks were inoculated with 
$10 \mathrm{~g}$ of alginate-chitosan beads containing immobilized cells. Repeated batch fermentations were performed with $L$ casei immobilized in alginate-chitosan beads to investigate the possibility of reusing the gel beads. The fermentation was carried out for $72 \mathrm{~h}$ in whey medium containing $145.5 \mathrm{~g} \mathrm{dm}^{-3}$ lactose. At the end of each run, the beads were washed with sterile physiological saline and transferred to fresh medium.

\section{Analytical techniques}

Lactose and lactic acid were analyzed by using HPLC (Perkin-Elmer, Norwalk, CT, USA) with an Aminex HPX-87H column (Bio-Rad Laboratories, Richmond, CA, USA) operated at $45^{\circ} \mathrm{C} . \mathrm{H}_{2} \mathrm{SO}_{4}\left(5 \mathrm{mmol} \mathrm{dm}{ }^{-3}\right)$ was used as the eluent at a flow rate of $0.6 \mathrm{~cm}^{3} \mathrm{~min}^{-1}$. Detection was effected using a refractive index detector (Perkin-Elmer). The data reported are the average values \pm SD of three replicate experiments.

Liquefaction of alginate-chitosan beads and Caalginate beads was performed by dissolving $1 \mathrm{~g}$ of beads in $20 \mathrm{~cm}^{-3}$ of $1 \%$ sodium citrate solution ( $\mathrm{pH}$ 6.0) with continuous stirring for $30 \mathrm{~min}$ at room temperature. To determine the concentration of viable cells entrapped in the beads and leaked cells from the gel beads, bacterial counts were performed by double plating appropriate dilutions ( $0.1 \%$ peptone) of liquefied beads and fermentation medium on MRS agar and incubating them at $37^{\circ} \mathrm{C}$ for $48 \mathrm{~h}$

Effective and conversion yields are expressed as the percentage of lactic acid produced per initial quantity of sugar in the medium and the percentage of lactic acid produced per quantity of sugar consumed, respectively.

\section{Experimental design and statistical analysis}

The statistical analysis of the data was performed using Minitab Statistical Software (Release 13.20). Details of RSM can be found elsewhere. ${ }^{30}$ The levels of factors used in the experimental design are listed in Table 1. The data for the factors were chosen after a series of preliminary experiments. Twenty experiments were conducted using a face central composite statistical design $(\alpha=1)$ for the study of three factors each at three levels (Table 2). The levels were $-1,0,+1$, where 0 corresponded to the central point. The actual level of the central point of each factor was calculated using the following

Table 1. Levels of factors used in the experimental design

\begin{tabular}{llrrr}
\hline & & \multicolumn{3}{c}{ Level } \\
\cline { 3 - 5 } Factor & \multicolumn{1}{c}{ Name } & -1 & 0 & +1 \\
\hline$X_{1}$ & Sugar concentration $\left(\mathrm{g} \mathrm{dm}^{-3}\right)$ & 120 & 150 & 180 \\
$X_{2}$ & ${\text { Yeast extract concentration }\left(\mathrm{g} \mathrm{dm}^{-3}\right)}_{10}$ & 30 & 50 \\
$X_{3}$ & $\mathrm{CaCO}_{3}$ concentration $\left(\mathrm{g} \mathrm{dm}^{-3}\right)$ & 30 & 50 & 70 \\
\hline
\end{tabular}

equation: ${ }^{30}$

$$
\text { coded value }=\frac{-(\text { high level }+ \text { low level }) / 2}{(\text { high level }+ \text { low level }) / 2}
$$

The response surface model was fitted to the response variable, namely lactic acid concentration $\left(\mathrm{g} \mathrm{dm}^{-3}\right)$. The second-order response function for three quantitative factors is given by

$$
\begin{aligned}
Y & =\beta_{0}+\beta_{1} X_{1}+\beta_{2} X_{2}+\beta_{3} X_{3}+\beta_{11} X_{1}^{2}+\beta_{22} X_{2}{ }^{2} \\
& +\beta_{33} X_{3}^{2}+\beta_{12} X_{1} X_{2}+\beta_{13} X_{1} X_{3}+\beta_{23} X_{2} X_{3}
\end{aligned}
$$

where $X_{1}, X_{2}$ and $X_{3}$ represent the levels of the factors according to Table 1 and $\beta_{0}, \beta_{1}, \ldots, \beta_{23}$ represent coefficient estimates with $\beta_{0}$ having the role of a scaling constant.

\section{RESULTS AND DISCUSSION \\ Kinetics of lactic acid production by $L$ case $i$ NRRL B-441 immobilized in alginate-chitosan beads and $\mathrm{Ca}$-alginate beads}

$L$ casei immobilized in alginate-chitosan beads and in Ca-alginate beads was used for lactic acid production from whey containing $145.5 \mathrm{~g} \mathrm{dm}^{-3}$ of initial sugar. As seen in Fig 1, higher lactic acid concentration $\left(125.6 \mathrm{~g} \mathrm{dm}^{-3}\right)$ was obtained after $72 \mathrm{~h}$ of fermentation by $L$ casei immobilized in alginate-chitosan beads. With Ca-alginate-immobilized cells, $116.2 \mathrm{~g} \mathrm{dm}^{-3}$ of lactic acid was produced at the end of $72 \mathrm{~h}$. As expected, the concentration of

\begin{tabular}{|c|c|c|c|c|}
\hline Run & $\begin{array}{c}\text { Sugar } \\
\text { concentration } \\
\left(\mathrm{g} \mathrm{dm}^{-3}\right)\end{array}$ & $\begin{array}{l}\text { Yeast extract } \\
\text { concentration } \\
\left(\mathrm{g} \mathrm{dm}^{-3}\right)\end{array}$ & $\begin{array}{c}\mathrm{CaCO}_{3} \\
\text { concentration } \\
\left(\mathrm{g} \mathrm{dm}^{-3}\right)\end{array}$ & $\begin{array}{l}\text { Lactic acid } \\
\text { concentration } \\
\left(\mathrm{g} \mathrm{dm}^{-3}\right)\end{array}$ \\
\hline 1 & 150 & 30 & 50 & 131.2 \\
\hline 2 & 120 & 50 & 70 & 125.6 \\
\hline 3 & 180 & 10 & 70 & 123.1 \\
\hline 4 & 150 & 30 & 50 & 131.3 \\
\hline 5 & 150 & 30 & 50 & 131.5 \\
\hline 6 & 120 & 10 & 70 & 125.0 \\
\hline 7 & 150 & 30 & 50 & 131.5 \\
\hline 8 & 150 & 30 & 50 & 131.2 \\
\hline 9 & 180 & 50 & 70 & 123.6 \\
\hline 10 & 120 & 10 & 30 & 120.6 \\
\hline 11 & 120 & 30 & 50 & 125.0 \\
\hline 12 & 150 & 10 & 50 & 129.2 \\
\hline 13 & 180 & 30 & 50 & 123.5 \\
\hline 14 & 150 & 30 & 50 & 131.3 \\
\hline 15 & 150 & 50 & 50 & 130.1 \\
\hline 16 & 150 & 30 & 30 & 128.7 \\
\hline 17 & 120 & 50 & 30 & 121.6 \\
\hline 18 & 180 & 10 & 30 & 119.0 \\
\hline 19 & 150 & 30 & 70 & 132.8 \\
\hline 20 & 180 & 50 & 30 & 120.5 \\
\hline
\end{tabular}
residual sugars decreased during the fermentation. After $72 \mathrm{~h}$ of fermentation, almost complete sugar

Table 2. Experimental design 


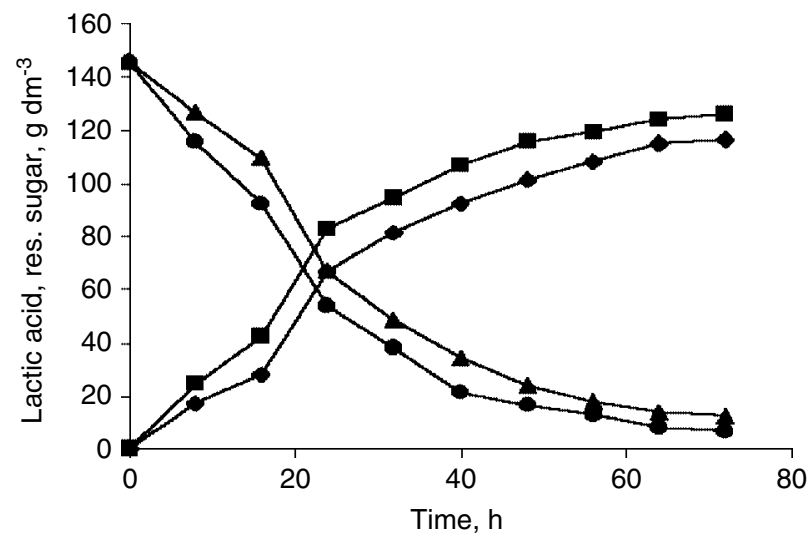

Figure 1. Kinetics of lactic acid production and lactose consumption by $L$ casei immobilized in alginate-chitosan beads $(\boldsymbol{\square}$, lactic acid; $\boldsymbol{\bullet}$, lactose) and Ca-alginate beads ( $\boldsymbol{\nabla}$, lactic acid; $\boldsymbol{\Delta}$, lactose) $\left(37^{\circ} \mathrm{C}, \mathrm{pH}\right.$ 5.5 , initial substrate concentration $145.5 \mathrm{~g} \mathrm{dm}^{-3}$; the standard deviation of each experimental point ranged from 1.4 to 3.7 ).

depletion was observed in both culture media. The residual sugar concentrations in the culture medium with alginate-chitosan beads and $\mathrm{Ca}$-alginate beads were 7.0 and $12.0 \mathrm{~g} \mathrm{dm}^{-3}$, respectively. Effective yield values of $86.3 \%$ and $79.9 \%$ and conversion yield values of $90.4 \%$ and $88.0 \%$ were obtained for alginate-chitosan beads and alginate beads, respectively. Maximum volumetric productivity values obtained for alginate-chitosan beads and alginate beads were 3.458 and $2.783 \mathrm{~g} \mathrm{dm}^{-3} \mathrm{~h}^{-1}$, respectively. Büyükkilleci and Harsa $^{4}$ produced lactic acid from whey using the free cells of $L$ casei NRRL B-441 and $95.3 \mathrm{~g} \mathrm{dm}^{-3}$ lactic acid was produced from an initial lactose concentration of $102.9 \mathrm{~g} \mathrm{dm}^{-3}$ with a maximum productivity of $2.30 \mathrm{~g} \mathrm{dm}^{-3} \mathrm{~h}^{-1}$.

Cell leakage in lactic acid production by immobilized lactic acid bacteria has been observed by various researchers..$^{5,6,9,19}$ In this study, the number of leaked cells in the fermentation medium comprised $3.2 \%$ of the total bacterial population with $\mathrm{Ca}$-alginate beads. Slightly lower cell leakage $(2.8 \%$ of the total bacterial population) was observed with alginate-chitosan beads. This proved that stabilization of alginate beads with chitosan decreased the cell leakage from beads.

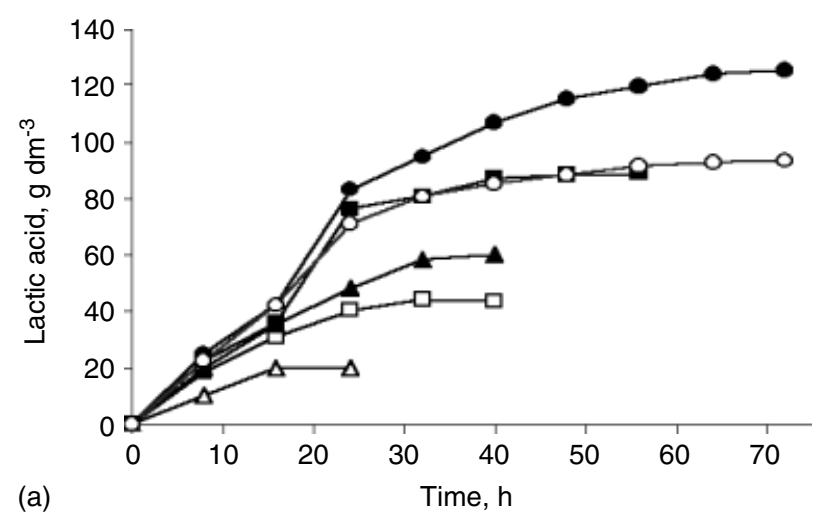

Alginate chitosan beads were also found to contain a higher number of entrapped cells $\left(5.12 \times 10^{9} \mathrm{cfu} \mathrm{g}^{-1}\right.$ beads) at the end of the fermentation owing to lower cell leakage from the beads compared with alginate beads $\left(4.50 \times 10^{9} \mathrm{cfu} \mathrm{g}^{-1}\right.$ beads). These results are in agreement with those of Zhou et al, ${ }^{19}$ who found that the cell release from uncoated alginate beads was greater than that for chitosan coated beads, indicating that the chitosan membrane did have a significant impact on reducing initial cell release from the beads. Since free cells comprised only $2.8 \%$ of the total bacterial population, lactic acid production by free cells in the system was considered to be negligible. Hence lactic acid production was mainly accomplished by immobilized bacterial cells.

Boyaval and Goulet $^{6}$ produced lactic acid from whey by Lactobacillus helveticus and found higher fermentation rates using Ca-alginate-entrapped cells compared with free cells. Roukas and Kotzekidou ${ }^{29}$ found that coimmobilized $L$ case $i$ and L lactis cells gave a higher overall lactic acid concentration compared with the free cell mixture owing to the stabilization of cellular activity. Cachon and Diviès ${ }^{31}$ reported immobilization as a tool to stabilize the activity of strains by preventing plasmid loss. Our results showed that immobilizing lactic acid bacteria in Ca-alginate beads coated with chitosan produces higher lactic acid concentration with lower cell leakage from the beads. This higher lactic acid production capacity of alginate-chitosan beads is attributed to their containing more immobilized and hence stabilized cell population compared with alginate beads.

\section{Effect of initial sugar concentration}

In order to determine the effect of lactose concentration on the final concentration of lactic acid produced by lactic acid bacteria entrapped in alginate-chitosan beads, diluted whey containing $22.7,50.1,70.0,99.1$, 145.5 and $180.0 \mathrm{~g} \mathrm{dm}^{-3}$ of lactose was used. Fermentation was performed in shake flasks at $37^{\circ} \mathrm{C}$ and $\mathrm{pH}$ 5.5. As seen in Fig 2(a), the final lactic acid concentration increased with increase in initial sugar concentration up to $145.5 \mathrm{~g} \mathrm{dm}^{-3}$ but then

Figure 2. Kinetics of lactic acid production (a) and lactose consumption (b) by $L$ casei immobilized in alginate-chitosan beads using different initial lactose concentrations $\left(\triangle, \square, \square, \boldsymbol{\Delta}, \boldsymbol{\square}, \boldsymbol{\bullet}, \mathrm{O} ; 22.7,50.1,70.0,99.1,145.5,180 \mathrm{~g} \mathrm{dm}^{-3}\right.$, respectively) (the standard deviation of each experimental point ranged from 2.2 to 4.8$)$. 
Table 3. Lactic acid, residual sugar, maximum lactic acid productivity, effective yield and conversion yield values obtained by alginate chitosan immobilized $L$ casei cells using different initial substrate concentrations

\begin{tabular}{lcccc}
\hline $\begin{array}{l}\text { Substrate } \\
\left(\mathrm{g} \mathrm{dm}^{-3}\right)\end{array}$ & $\begin{array}{c}\text { Lactic acid } \\
\left(\mathrm{g} \mathrm{dm}^{-3}\right)\end{array}$ & $\begin{array}{c}\text { Residual sugar } \\
\left(\mathrm{g} \mathrm{dm}^{-3}\right)\end{array}$ & $\begin{array}{c}\text { Maximum } \\
\text { productivity }\left(\mathrm{g} \mathrm{dm}^{-3} \mathrm{~h}^{-1}\right)\end{array}$ & $\begin{array}{c}\text { Effective } \\
\text { yield }(\%)\end{array}$ \\
\hline 22.7 & 20.1 & 0 & 1.238 & 88.5 \\
50.1 & 44.1 & 0 & 2.313 & 79.8 \\
70.0 & 60.0 & 0 & 2.438 & 85.7 \\
99.1 & 89.0 & 0 & 2.788 & 89.8 \\
145.5 & 125.6 & 8 & 3.458 & 87.6 \\
180.0 & 93.1 & 35.8 & 2.954 & 89.8 \\
\hline
\end{tabular}

significantly decreased beyond this value. The highest concentration of lactic acid $\left(125.6 \mathrm{~g} \mathrm{dm}^{-3}\right)$ was obtained after $72 \mathrm{~h}$ with an initial sugar concentration of $145.5 \mathrm{~g} \mathrm{dm}^{-3}$. The lactic acid and residual sugar concentrations together with maximum productivity, effective yield and conversion yield values obtained in whey medium containing 22.7, 50.1, 70.0, $99.1,145.5$ and $180.0 \mathrm{~g} \mathrm{dm}^{-3}$ of lactose are given in Table 3. The effective yield gave a peak at an initial sugar concentration of $99.1 \mathrm{~g} \mathrm{dm}^{-3}$ and the conversion yield gave a peak at $145.5 \mathrm{~g} \mathrm{dm}^{-3} \mathrm{~h}^{-1}$. When the initial sugar concentration exceeded $145.5 \mathrm{~g} \mathrm{dm}^{-3}$, the yield values decreased owing to inhibition produced by high sugar concentration. Substrate inhibition in lactic acid production has also been reported by other workers. ${ }^{3-5}$

As shown in Fig 2(b), the concentration of residual sugars declined continuously during fermentation, following an inverse trend to that of lactic acid concentration. Increasing the initial sugar concentration from 145.5 to $180 \mathrm{~g} \mathrm{dm}^{-3}$ resulted in a significant increase in residual sugar concentration. This was expected since there was also a decrease in lactic acid concentration. Kotzamanidis $e t \mathrm{al}^{3}$ studied lactic acid production from beet molasses by Lactobacillus delbrueckii and stated that the increase in residual sugars by the increase of initial sugar concentration in the medium was due to the inability of microorganisms to metabolize high levels of sugars.

\section{Effect of Na-alginate concentration}

$L$ casei was immobilized in alginate-chitosan beads prepared from different concentrations of $\mathrm{Na}$-alginate $(1.0,2.0$ and $3.0 \%(\mathrm{w} / \mathrm{v}))$ and lactic acid production was investigated in whey medium containing $145.5 \mathrm{~g} \mathrm{dm}^{-3}$ lactose initially. The fermentation was carried out for $72 \mathrm{~h}$. Similar lactic acid concentrations were obtained for $\mathrm{Na}$-alginate concentrations of 1.0 and $2.0 \%$ (127.8 and $125.6 \mathrm{~g} \mathrm{dm}^{-3}$, respectively). Above $2.0 \% \mathrm{Na}$-alginate concentration, lactic acid production decreased $\left(113.5 \mathrm{~g} \mathrm{dm}^{-3}\right)$ owing to the lower diffusion efficiency of the beads. Maximum lactic acid production $\left(127.8 \mathrm{~g} \mathrm{dm}^{-3}\right)$, effective yield $(87.8 \%)$ and conversion yield $(93.0 \%)$ were obtained with beads prepared from $1 \%(\mathrm{w} / \mathrm{v}) \mathrm{Na}$-alginate. However, beads prepared from $1.0 \% \mathrm{Na}$-alginate were soft and highly susceptible to compaction and disintegration during lactic acid production and most of them disrupted in the medium at the end of fermentation. This result is in agreement with that of Göksungur et $a l,{ }^{5}$ who produced lactic acid from beet molasses by Ca-alginate immobilized Lactobacillus delbrueckii and found that beads prepared from 1.0 and $1.5 \% \mathrm{Na}$ alginate disrupted in the medium owing to their soft structure. Abdel-Naby et $a l^{32}$ investigated lactic acid production by calcium alginate-immobilized $L$ lactis and determined the maximum lactic acid production with beads containing 3\% Ca-alginate. Owing to diffusion problems, they obtained lower yields with the beads made of 4 and $5 \%$ alginate.

Alginate is a family of unbranched binary copolymers of $(1 \rightarrow 4)$-linked $\beta$-D-mannuronic acid and $\alpha$-L-guluronic acid. It has widely varying composition and sequential structure. Alginate gels with a high guluronic acid content are mechanically stronger and exhibit high porosity and low shrinkage during gel formation. By increasing the mannuronic acid content, the gels become softer and more elastic. Thus, the proportion and the length of guluronic acid units is the main structural feature contributing to gel formation. ${ }^{33}$ Therefore, data cited in the above references are subject to some variation depending on the alginate provenance since alginates are susceptible to batch-to-batch and supplier-to-supplier variations.

\section{Effect of bead diameter}

The effect of bead diameter (1.3-1.7, 2.0-2.4, $2.8-3.2 \mathrm{~mm}$ ) on lactic acid production was investigated using alginate - chitosan gel beads containing $2 \%$ $(\mathrm{w} / \mathrm{v})$ Na-alginate. The highest lactic acid concentration $\left(131.2 \mathrm{~g} \mathrm{dm}^{-3}\right)$ was obtained with cells entrapped in $1.3-1.7 \mathrm{~mm}$ beads. Lactic acid concentrations obtained with $2.0-2.4$ and $2.8-3.2 \mathrm{~mm}$ beads were 125.6 and $111.4 \mathrm{~g} \mathrm{dm}^{-3}$, respectively. The highest effective yield $(90.2 \%)$ and conversion yield $(95.4 \%)$ were obtained with $1.3-1.7 \mathrm{~mm}$ alginate-chitosan beads. Smaller beads yielded more lactic acid owing to an increase in surface-to-volume ratio. A gradual increase in bead diameter beyond $2.4 \mathrm{~mm}$ resulted in a gradual decrease in lactic acid production due to development of a mass transfer barrier. Moreover, limited nutrient availability inside the beads was probably another factor that decreased the fermentation efficiency of larger diameter alginate-chitosan beads. Göksungur et $a l^{5}$ and Abdel-Naby et al ${ }^{32}$ obtained 
maximum lactic acid production with cells entrapped in Ca-alginate beads with bead diameters of 2.0-2.4 and $2.0-2.2 \mathrm{~mm}$, respectively.

\section{Production of lactic acid using repeated batch fermentations}

Repeated batch fermentations were carried out with $L$ casei cells immobilized in $1.3-1.7 \mathrm{~mm}$ alginate-chitosan beads to investigate the possibility of reusing cells. As shown in Fig 3, alginate-chitosanimmobilized cells were reused successfully for five continuous runs without marked activity loss. The highest lactic acid production $\left(131.7 \mathrm{~g} \mathrm{dm}^{-3}\right)$ was obtained in the third run and after the sixth run a gradual decrease was observed in lactic acid production. Lactic acid was produced with alginate-chitosan beads for a total of 10 runs but shrinkage, deformation and small cracks on the surface of beads were observed in the last two runs. The beads lost their hardness and completely disrupted in the medium at the end of the 11 th run. Lactic acid production in the 11 th run was thought to result from the activity of free cells in the medium.

Roukas and Kotzekidou ${ }^{29}$ coimmobilized $L$ case $i$ and $L$ lactis cells in Ca-alginate and found that the beads retained their ability to produce lactic acid for 20 days. Hang et $a l^{34}$ produced lactic acid from glucose by Ca-alginate-immobilized Rhizopus oryzae cells and reported that the beads produced lactic acid for 17 days without loss of activity. Göksungur and Güvenç ${ }^{5}$ produced lactic acid from molasses using Ca-alginate-immobilized $L$ delbrueckii for 14 consecutive batch fermentations without marked activity loss and deformation. Ca-alginate beads were also reused successfully 15 times by Guoqiang et $a l^{35}$ and eight times by Abdel-Naby et al. ${ }^{32}$ This ability of immobilized cells to produce lactic acid for a long time has not been explained clearly. Roukas and Kotzekidou ${ }^{27}$ attributed this ability of immobilized cells to produce lactic acid for a long time to the protection of cells by the

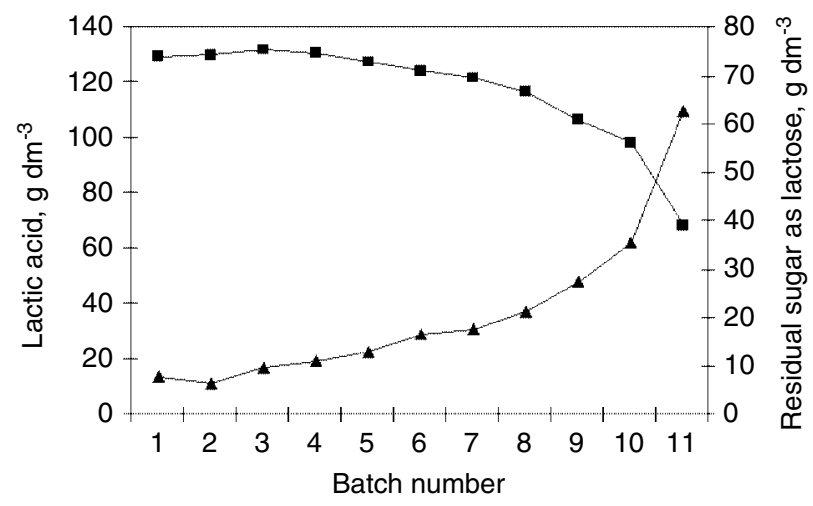

Figure 3. Lactic acid and residual sugar concentrations during repeated batch fermentation of whey by alginate-chitosan entrapped $L$ casei ( $\boldsymbol{\square}$, lactic acid; $\boldsymbol{\Delta}$, lactose) $\left(37^{\circ} \mathrm{C}, \mathrm{pH} 5.5\right.$, initial substrate concentration $145.5 \mathrm{~g} \mathrm{dm}^{-3}$, Na-alginate concentration $2.0 \%$, bead diameter 1.3-1.7 $\mathrm{mm}$; the standard deviation of each experimental point ranged from 1.2 to 3.9 ). immobilization matrix. Rychtera et $a l^{36}$ reported that immobilized cells can retain enzyme activities for a long time owing to the different compositions of cells (proteins, lipids, RNA, DNA and inorganic substances) compared with free cells. Cachon and Diviès $^{31}$ stated that high cell densities in the immobilization matrix and high dilution rates obtained in the continuous fermentation system allow the protection of immobilized cells from contamination. They also reported that immobilization stabilized the activity of strains by preventing plasmid loss.

\section{Optimization of lactic acid production}

In lactic acid production, yeast extract supplementation is one of the key applications in providing amino acids, vitamins and cofactors required for cell maintenance. ${ }^{4}$ Calcium carbonate is another important factor since it neutralizes the acid formed and thus prevents its inhibitory effect on the growth of cells and helps to maintain the mechanical structure of alginate gel beads in immobilized cells. ${ }^{5}$ RSM was used to determine the optimum concentrations of initial sugar, yeast extract and $\mathrm{CaCO}_{3}$, leading to maximum lactic acid production. The effects of the three previously mentioned variables, each at three levels, and their interactions on lactic acid production were determined using a face centered design. Analysis of variance (ANOVA) for the concentration of lactic acid is presented in Table 4 . The analysis gives the value of the model and determines the requirement of a more complex model with a better fit. If the $F$-test for lack of fit is significant, then a more complicated model is needed. As shown in Table $4, R^{2}$ is 0.999 , which indicates that the model as fitted explained $99.9 \%$ of the variability in lactic acid concentration. The $F$-test for regression was significant at a level of $5 \%(p<0.05)$. Also, the lack of fit was not significant at the $5 \%$ level $(p>0.05)$. These results show that the model chosen can satisfactorily explain the effects of initial sugar, yeast extract and $\mathrm{CaCO}_{3}$ concentrations on lactic acid production by $L$ casei using whey. The following model was fitted for lactic acid concentration:

$$
\begin{aligned}
Y & =-52.019+2.296 X_{1}+0.26698 X_{2}+0.2524 X_{3} \\
& -0.007711 X_{1}^{2}-0.003911 X_{2}^{2}-0.00105 \\
& X_{3}{ }^{2}-0.0002408 X_{1} X_{3}-0.000426 X_{2} X_{3}
\end{aligned}
$$

Table 4. ANOVA for lactic acid concentration $\left(R^{2}=0.999\right)$

\begin{tabular}{lrrrrrc}
\hline Source & DF & Seq SS & Adj SS & Adj MS & $F$ & $p$ \\
\hline Regression & 9 & 388.41 & 388.41 & 43.16 & 2000 & 0.000 \\
Linear & 3 & 47.50 & 172.49 & 57.50 & 2000 & 0.000 \\
Square & 3 & 340.50 & 340.50 & 113.50 & 4000 & 0.000 \\
Interaction & 3 & 0.42 & 0.42 & 0.14 & 5.06 & 0.022 \\
Residual error & 10 & 0.27 & 0.27 & 0.027 & & \\
Lack of fit & 5 & 0.17 & 0.17 & 0.034 & 1.63 & 0.30 \\
Pure error & 5 & 0.10 & 0.10 & 0.021 & & \\
Total & 19 & 388.68 & & & & \\
\hline
\end{tabular}

DF, degrees of freedom; Seq SS, sequential sum of squares; Adj SS, adjusted sum of squares; Adj $M$, adjusted mean square. 
Table 5. Estimated regression coefficients for lactic acid concentration

\begin{tabular}{lccrr}
\hline Term & Coefficient & SE coefficient & $T$ & $p$ \\
\hline Constant & -52.019 & 2.400 & -21.67 & 0.000 \\
Sugar concentration & 2.296 & 0.0338 & 67.92 & 0.000 \\
Yeast extract concentration & 0.267 & 0.0223 & 11.95 & 0.000 \\
$\mathrm{CaCO}_{3}$ concentratıon & 0.252 & 0.0294 & 8.59 & 0.000 \\
Sugar $\times$ Sugar & -0.0077 & 0.00011 & -69.52 & 0.000 \\
Yeast extract $\times$ Yeast extract & -0.0039 & 0.00025 & -15.67 & 0.000 \\
$\mathrm{CaCO}_{3} \times \mathrm{CaCO}_{3}$ & -0.0011 & 0.00025 & -4.20 & 0.002 \\
Sugar $\times \mathrm{Yeast} \mathrm{extract}_{\text {Sugar } \times \mathrm{CaCO}_{3}}$ & 0.000076 & 0.00010 & 0.78 & 0.453 \\
Yeast extract $\times \mathrm{CaCO}_{3}$ & -0.00024 & 0.00010 & -2.47 & 0.033 \\
\hline
\end{tabular}

$T$, test coefficient.

where $X_{1}, X_{2}$ and $X_{3}$ are the actual levels of factors shown in Table 1. Table 5 shows that initial sugar, yeast extract and $\mathrm{CaCO}_{3}$ concentrations have a strong positive linear effect on the response, which is lactic acid concentration $(p \ll 0.05)$. There were also significant negative quadratic effects of the above factors, indicating that lactic acid concentration increases with increase in these parameters, but decreases as the above parameters are increased at high levels. Additionally, a significant negative interaction effect was observed between initial sugar and $\mathrm{CaCO}_{3}$ and also yeast extract and $\mathrm{CaCO}_{3}$. This indicated that lactic acid concentration increased with the increase in these parameters; they reached a maximum and then decreased at high levels of the given factors. Finally, no significant interaction effect $(p>0.05)$ was noted between initial sugar and yeast extract and hence this coefficient $\left(X_{1} X_{2}\right)$ was omitted in eqn (2).

Figures 4-6 show the contour plots of lactic acid concentration for each pair of factors whereas the third factor was kept constant at its middle level. Figure 4 identifies optima for the yeast extract and initial sugar concentrations for the given $\mathrm{CaCO}_{3}$ concentration. As shown in Fig 4, the maximum concentration of lactic acid was observed around $32 \mathrm{~g} \mathrm{dm}^{-3}$ yeast extract and $146 \mathrm{~g} \mathrm{dm}^{-3}$ initial sugar concentrations.

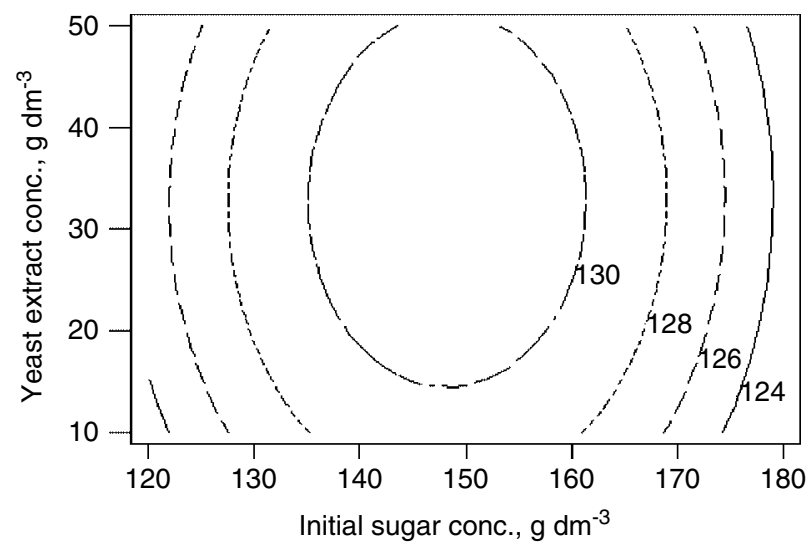

Hold values: $\mathrm{CaCO}_{3}: 50.0 \mathrm{~g} \mathrm{dm}^{-3}$

Figure 4. Contour plot for lactic acid concentration at varying concentrations of yeast extract and initial sugar at a constant $\mathrm{CaCO}_{3}$ concentration $\left(50 \mathrm{~g} \mathrm{dm}^{-3}\right)$.

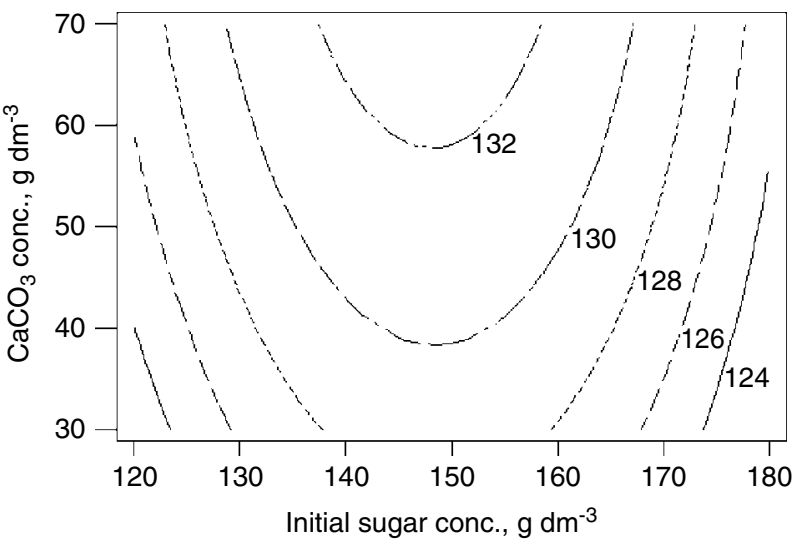

Hold values: Yeast Extract: $30.0 \mathrm{~g} \mathrm{dm}^{-3}$

Figure 5. Contour plot for lactic acid concentration at varying concentrations of $\mathrm{CaCO}_{3}$ and initial sugar at a constant yeast extract concentration $\left(30 \mathrm{~g} \mathrm{dm}^{-3}\right)$.

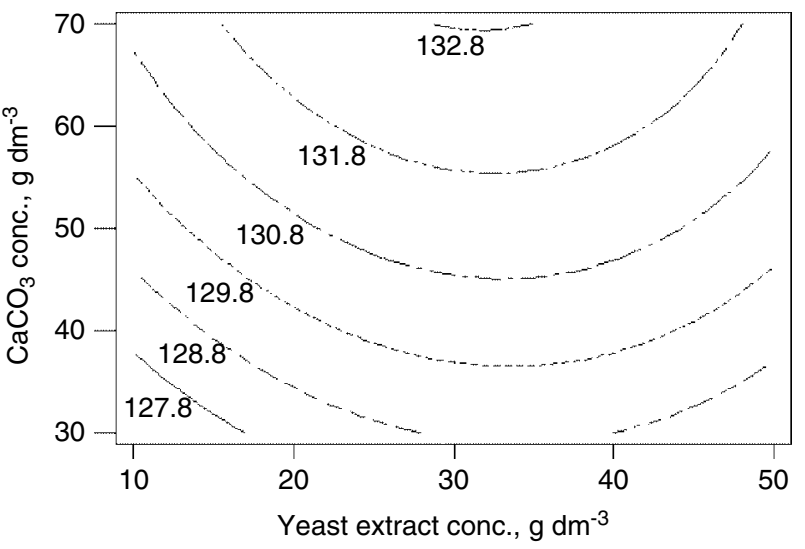

Hold values: Initial sugar: $150.0 \mathrm{~g} \mathrm{dm}^{-3}$

Figure 6. Contour plot for lactic acid concentration at varying concentrations of $\mathrm{CaCO}_{3}$ and yeast extract at a constant initial sugar concentration $\left(150 \mathrm{~g} \mathrm{dm}^{-3}\right)$.

Moreover, for the same levels of yeast extract or initial sugar concentrations, the concentration of lactic acid decreased from the middle to high yeast extract or initial sugar levels. Figure 5 shows that lactic acid concentration increased with increase in initial sugar and $\mathrm{CaCO}_{3}$ concentrations and further increases in the above factors resulted in a decrease in lactic acid concentration. Finally, Fig 6 shows how lactic 
acid production by alginate-chitosan-immobilized $L$ casei varies with yeast extract and $\mathrm{CaCO}_{3}$ concentrations at a fixed initial sugar concentration $\left(150 \mathrm{~g} \mathrm{dm}^{-3}\right)$. As can be seen from Fig 6, lactic acid concentration increased with increase in yeast extract and $\mathrm{CaCO}_{3}$ concentrations within a certain range and then fell at the extreme low or high levels of these factors. Figures 5 and 6 demonstrate that the optima derived from Fig 4 remain largely unchanged. In both cases, increasing the $\mathrm{CaCO}_{3}$ concentration increased the lactic acid production when the yeast extract or initial sugar concentration was held constant while the other two variables were adjusted. In order to determine the maximum lactic acid concentration corresponding to the optimum levels of initial sugar, yeast extract and $\mathrm{CaCO}_{3}$ concentrations, a second-order polynomial model was used to calculate the values of these variables. The fitting of the experimental data to eqn (2) allowed the determination of the concentrations of initial sugar $\left(X_{1} 147.35 \mathrm{~g} \mathrm{dm}^{-3}\right)$, yeast extract $\left(X_{2} 28.81 \mathrm{~g} \mathrm{dm}^{-3}\right)$ and calcium carbonate $\left(X_{3} 97.55 \mathrm{~g} \mathrm{dm}^{-3}\right)$ giving a maximum lactic acid concentration of $133.31 \mathrm{~g} \mathrm{dm}^{-3}$. The above data optimize lactic acid production from whey by alginate-chitosan-immobilized $L$ casei.

The final fermentation was performed in whey by alginate-chitosan-immobilized $L$ casei at the optimized concentrations of initial sugar $\left(147.35 \mathrm{~g} \mathrm{dm}^{-3}\right)$, yeast extract $\left(28.81 \mathrm{~g} \mathrm{dm}^{-3}\right)$ and $\mathrm{CaCO}_{3}\left(97.55 \mathrm{~g} \mathrm{dm}^{-3}\right)$ given by the model. The alginate-chitosan beads $(1.3-1.7 \mathrm{~mm})$ were prepared from $2 \%$ Na-alginate. A maximum lactic acid concentration $\left(136.3 \mathrm{~g} \mathrm{dm}^{-3}\right)$ which was slightly higher than the value given by the model was obtained at the 72 nd hour of fermentation. The maximum lactic acid productivity $\left(3.708 \mathrm{~g} \mathrm{dm}^{-3} \mathrm{~h}^{-1}\right)$ was obtained at the 24 th hour of fermentation.

\section{CONCLUSIONS}

In this study, lactic acid was produced from whey by $L$ casei NRRL B-441 immobilized in chitosanstabilized Ca-alginate beads. Coating Ca-alginate beads with chitosan stabilized the beads and led to higher lactic acid production and lower cell leakage compared with uncoated $\mathrm{Ca}$-alginate beads. Optimum fermentation activity was obtained with $1.3-1.7 \mathrm{~mm}$ diameter alginate-chitosan beads prepared from $2 \% \mathrm{Na}$-alginate. Alginate-chitosan beads were used consecutively for five runs without marked activity loss in repeated batch fermentation studies.

RSM was used to determine the effects of three important factors (initial sugar, yeast extract and calcium carbonate concentrations) on lactic acid production from whey. Linear, quadratic and interaction effects of these variables on lactic acid production were determined. The model generated in this study by RSM satisfied all the necessary arguments for its use in optimization. By fitting the experimental data to a second-order polynomial equation, the optimum levels of the above-mentioned variables were determined. Using the optimum levels of fermentation parameters, a maximum lactic acid concentration of $136.3 \mathrm{~g} \mathrm{dm}^{-3}$ was obtained. This study indicates that the medium design using statistical techniques such as RSM can be very useful in improving the production of lactic acid by immobilized cells and in similar bioprocesses.

\section{REFERENCES}

1 Vick Roy TB, Lactic acid, in Comprehensive Biotechnology, ed by Young MM. Pergamon Press, New York, Vol 3, pp 761-776 (1985).

2 Dunn RL, English JP, Stropel JD, Cowsar DK and Tice TR, Preparation and evaluation of lactide/glycolide copolymers for drug delivery, in Polymers in Medicine III, ed by Migliaresi C. Elsevier, Amsterdam, pp 149-159 (1988).

3 Kotzamanidis $\mathrm{CH}$, Roukas T and Skaracis G, Optimization of lactic acid production from beet molasses by Lactobacillus delbrueckii NCIMB 8130. World f Microbiol Biotechnol 18:441-448 (2002).

4 Büyükkilleci AO and Harsa S, Batch production of L-(+)-lactic acid from whey by Lactobacillus casei (NRRL B-441). 7 Chem Technol Biotechnol 79:1036-1040 (2004).

5 Göksungur Y and Güvenç U, Production of lactic acid from beet molasses by calcium alginate immobilized Lactobacillus delbrueckii IFO 3202. F Chem Technol Biotechnol 74:131-136 (1999).

6 Boyaval P and Goulet J, Optimal conditions for production of lactic acid from cheese whey permeate by Ca-alginateentrapped Lactobacillus helveticus. Enzyme Microbiol Technol 10:725-728 (1988).

7 Audet P, Paquin C and Lacroix C, Sugar utilization and acid production by free and entrapped cells of Streptococcus salivarius subsp. thermophilus, Lactobacillus delbrueckii subsp. bulgaricus and Lactococcus lactis subsp. lactis in a whey permeate medium. Appl Environ Microbiol 55:185-189 (1989).

$8 \mathrm{LiX}$, The use of chitosan to increase the stability of calcium alginate beads with entrapped yeast cells. Biotechnol Appl Biochem 23:269-271 (1996).

9 Tanaka H, Irie S and Ochi H, A novel immobilization method for prevention of cell leakage from the gel matrix. $\mathcal{F}$ Ferment Bioeng 68:216-219 (1989).

10 Champagne CP, Gaudy C, Poncelet D and Neufeld RJ, Lactococcus lactis release from calcium alginate beads. Appl Environ Microbiol 58:1429-1434 (1992).

11 Bódalo A, Bastida J, Gómez JL, Gómez E, Alcaraz I and Asanza ML, Stabilization studies of L-aminoacylaseproducing Pseudomonas sp BA2 immobilized in calcium alginate gel. Enzyme Microbiol Technol 21:64-69 (1997).

12 Rymowicz W, Wojtatowicz M, Robak M and Jurgielewicz W, The use of immobilized Yarrowia lipolytica cells in Ca-alginate for citric acid production. Acta Microbiol Pol 42:163-170 (1993).

13 Göksungur Y, Optimization of the production of chitosan from beet molasses by response surface methodology. $\mathcal{f}$ Chem Technol Biotechnol 79:974-981 (2004).

14 Albarghouthi M, Fara DA, Saleem M, El-Thaher T, Matalka K and Badwan A, Immobilization of antibodies on alginate-chitosan beads. Int F Pharm 206:23-34 (2000).

15 Taqicddin E and Amiji M, Enzyme immobilization in novel alginate-chitosan core-shell microcapsules. Biomaterials 25:1937-1945 (2004).

16 Gåserød O, Smidsrød O and Skjåk-Bræk G, Microcapsules of alginate-chitosan-I. A quantitative study of the interaction between alginate and chitosan. Biomaterials 19:1815-1825 (1998). 
17 Gåserød O, Sannes A and Skjåk-Bræk G, Microcapsules of alginate-chitosanm-II. A study of capsule stability and permeability. Biomaterials 20:773-783 (1999).

18 Yoo IK, Seong GH, Chang HN and Park JK, Encapsulation of Lactobacillus casei cells in liquid-core alginate capsules for lactic acid production. Enzyme Microbiol Technol 19:428-433 (1996).

19 Zhou Y, Martins E, Groboillot A, Champagne CP and Neufeld RJ, Spectrophotometric quantification of lactic bacteria in alginate and control of cell release with chitosan coating. $\mathcal{f}$ Appl Microbiol 84:342-348 (1998).

$20 \mathrm{Li} \mathrm{C}$, Bai J, Cai Z and Ouyang F, Optimization of a cultural medium for bacteriocin production by Lactotococcus lactis using response surface methodology. F Biotechnol 93:27-34 (2002).

21 Monteagudo JM, Rincon J, Rodriguez L, Fuertes J and Moya A, Determination of the best nutrient medium for the production of L-lactic acid from beet molasses. A statistical approach. Acta Biotechnol 13:103-110 (1993).

22 Monteagudo JM, Rodriguez L, Rincon J and Fuertes J, Optimization of the conditions of the fermentation of beet molasses to lactic acid by Lactobacillus delbrueckii. Acta Biotechnol 14:251-260 (1994).

23 Tuli A, Sethi RP, Khanna PK, Marwal SS and Kennedy JF, Lactic acid production from whey permeate by immobilized Lactobacillus casei. Enzyme Microb Technol 7:164-168 (1985).

24 Roy D and Goulet J, Continuous production of lactic acid from whey permeate by free and calcium alginate antrapped Lactobacillus helveticus. F Dairy Sci 70:506-513 (1987).

25 Krischke W, Schröder M and Trösch W, Continuous production of lactic acid from whey permeate by immobilized Lactobacillus casei subsp. casei. Appl Microbiol Biotechnol 34:573-578 (1991).

26 Norton S, Lacroix C and Vuillemard JC, Kinetic study of continuous whey permeate fermentation by immobilized Lactobacillus helveticus for lactic acid production. Enzyme Microbiol Technol 16:457-466 (1994).

27 Roukas T and Kotzekidou P, Production of lactic acid from deproteinized whey by coimmobilized Lactobacillus casei and Lactococcus lactis cells. Enzyme Microb Technol 13:33-38 (1991)
28 Roukas $\mathrm{T}$ and Kotzekidou $\mathrm{P}$, Continuous production of lactic acid from deproteinized whey by coimmobilized Lactobacillus casei and Lactococcus lactis cells in a packed-bed reactor. Food Biotechnol 10:231-242 (1996).

29 Roukas $\mathrm{T}$ and Kotzekidou P, Lactic acid production from deproteinized whey by mixed cultures of free and coimmobilized Lactobacillus casei and Lactococcus lactis cells using fedbatch culture. Enzyme Microb Technol 22:199-204 (1998).

30 Neter J, Kutner MH, Nachtsheim CJ and Wasserman W, Applied Linear Statistical Models, 4th edn. McGraw-Hill, Chicago (1996).

31 Cachon $\mathrm{R}$ and Diviès C, Difference of behaviour between free and immobilized lactic acid bacteria, in Proceedings of the First Lactic Acid Bacteria Computer Conference, ed by Foo EL, Griffin R, Moellby $\mathrm{R}$ and Heden CG. Horizon Scientific Press, Wymondham, pp 69-71 (1993).

32 Abdel-Naby M, Mok C and Lee C, Production of organic acids from enzymatic hydrolyzate of starch by immobilized lactic acid bacteria. In Proceedings of the UNIDO International Workshop on Lactic Acid Fermentation of Non-Dairy Food and Beverages, Songnam, Korea, 25-27 fune 1992. pp 227-243 (1992).

33 Skjåk-Bræk G, Alginates: biosyntheses and some structure-function relationships relevant to biomedical and biotechnological applications. Biochem Soc Trans 20:27-33 (1992).

34 Hang Y, Hamamc1 $\mathrm{H}$ and Woodams EE, Production of L-(+)lactic acid by Rhizopus oryzae immobilized in calcium alginate gels. Biotechnol Lett 11:119-120 (1989).

35 Guoqiang D, Kaul R and Mattiasson B, Evalution of alginateimmobilized Lactobacillus casei for lactate production. Appl Microbiol Biotechnol 36:309-314 (1991).

36 Rychtera M, Basarova G and Ivanova V, Behavior and properties of released and in calcium alginate gel immobilized cells of Saccharomyces cerevisiae in continuous culture, in 4th European Congress on Biotechnology Vol 2, ed by Neijssel OM, van der Meer RR and Luvben K. Elsevier, Amsterdam pp 107-109 (1987). 